\section{Gibberellic Acid-induced Fruit Set of Rabbiteye Blueberry following Freeze and Physical Injury}

\author{
D. Scott NeSmith ${ }^{1}$ \\ Department of Horticulture, Georgia Station, Griffin, GA, 30223-1797
}

Gerard Krewer ${ }^{1}$

Department of Horticulture, The University of Georgia, P.O. Box 1209, Tifton, GA 31793

\author{
Mark Rieger ${ }^{1}$ \\ Department of Horticulture, The University of Georgia, Athens, GA 30602
}

Ben Mullinix ${ }^{2}$

Statistical Services, The University of Georgia, P.O. Box 748, Tifton, GA 31793

Additional index words. Vaccinium ashei, growth regulator

Abstract. In a series of experiments, gibberellic acid $\left(\mathbf{G A}_{3}\right)$ was applied to rabbiteye blueberries (Vaccinium ashei Reade) under field and greenhouse conditions to determine if fruit set could be improved following physical or freeze injury to flowers. In field experiments, physically damaged flowers (i.e., corollas and styles removed, styles only removed, or ovaries lanced) of 'Climax' and 'Tifblue' treated with $\mathrm{GA}_{3}$ (4\% ProGib at 250 mg.liter $^{-1}$ ) set substantially more fruit than nontreated, damaged flowers. Under greenhouse conditions, $\mathbf{G A}_{3}$ applied postfreeze to 'Tifblue' and 'Brightwell' resulted in increased fruit set compared to unsprayed control plants of the same cultivars. Freezedamaged plants had substantially reduced fruit set overall but to a much lesser extent for $\mathbf{G A}_{3}$-treated plants than for those not treated with $\mathbf{G A}_{3}$. Individual fruit weight was reduced by $\mathrm{GA}_{3}$ applications, as was berry seediness. Results from these greenhouse and field trials suggest that $\mathrm{GA}_{3}$ can be used to salvage a blueberry crop following a moderate freeze during bloom.

Freeze damage is a peril faced by blueberry growers throughout the southeastern United States and other growing regions. Some degree of crop damage (i.e., fruit loss) occurs almost every year in some location. Eck (1988) has suggested that $60 \%$ to $80 \%$ of blueberry flowers must set fruit to attain fair to excellent commercial yields. Hence, even a mild freeze that only slightly damages flowers can result in economic losses. A means of reducing blueberry fruit losses due to freeze injury would have immediate economic impact.

Barker and Collins (1965) demonstrated parthenocarpic fruit set of blueberry was possible with exogenous applications of gibberellic acid $\left(\mathrm{GA}_{3}\right)$. Subsequent experiments indi-

Received for publication 9 Mar. 1995. Accepted for publication 27 June 1995. A contribution of the Univ. of Georgia Agriculture Expt. stations, Georgia Station, Griffin. This research was supported by state and Hatch Act funds allocated to the Georgia Agr. Expt. stations and by grant funds received from Michigan Blueberry Growers Association and Abbott Laboratory. We gratefully acknowledge the assistance of Stanley Scarborough, James Clark, and Jimmy Land for participation in this research. The cost of publishing this paper was defrayed in part by the payment of page charges. Under postal regulations, this paper therefore must be hereby marked advertisement solely to indicate this fact.

${ }^{1}$ Associate Professor.

${ }^{2}$ Statistician.

HortScience, Vol. 30(6), OCtober 1995 rabbiteye blueberries (Austin, 1979; Davies, 1986; Davies and Buchanan, 1979; Mainland the time of freeze and $\mathrm{GA}_{3}$ treatments. et al., 1979). NeSmith and Krewer (1992) revealed that the activity of the growth regulator depends on flower bud stage. As a result, $\mathrm{GA}_{3}$ applications have become a commercial practice over the past few years in Georgia to increase fruit set and yield of rabbiteye blueberry, especially in large fields where pollination is often inadequate.

Zucconi and Bukovac (1978) reported stimulation of growth of freeze-injured peach [Prunus persica (L). Batsch.] fruit by $\mathrm{GA}_{3}$. Also, Modlibowska (1975) found that gibberellins applied after decapitation of styles increased yield of 'Bramley' apples (Malus domestica Borkh.) by inducing parthenocarpic fruit set. In 1993, preliminary field trials with $\mathrm{GA}_{3}$ indicated that it might have value in salvaging a blueberry crop following freeze injury to flowers; postfreeze applications of $\mathrm{GA}_{3}$ appeared to prevent abscission of damaged flowers, and these flowers later set fruit. Our objective was to test whether $\mathrm{GA}_{3}$ could be used to salvage a crop following physical and freeze injury to rabbiteye blueberry flowers.

\section{Materials and Methods}

Induced freeze damage. One-year-old potted 'Tifblue' and 'Brightwell' blueberry plants were obtained from a commercial nursery in Fall 1993. Beginning in Dec. 1993, these plants were held for $700 \mathrm{~h}$ in a dark cooler at $7 \pm 2 \mathrm{C}$ to be chilled. After chilling, all plants were placed in a greenhouse (receiving only natural sunlight) at a $24 \mathrm{C}$ day/18C night regime to force bloom. There were 24 plants each of 'Tifblue' and 'Brightwell'. When plants reached stage 5 to 6 of bud development (Spiers, 1978), treatments were imposed (23 Feb. 1994). Treatments at stage 5 and 6 of bud development consisted of a $2 \times 2$ factorial arrangement of freezing and $\mathrm{GA}_{3}$ applications. Half of the plants were subjected to a

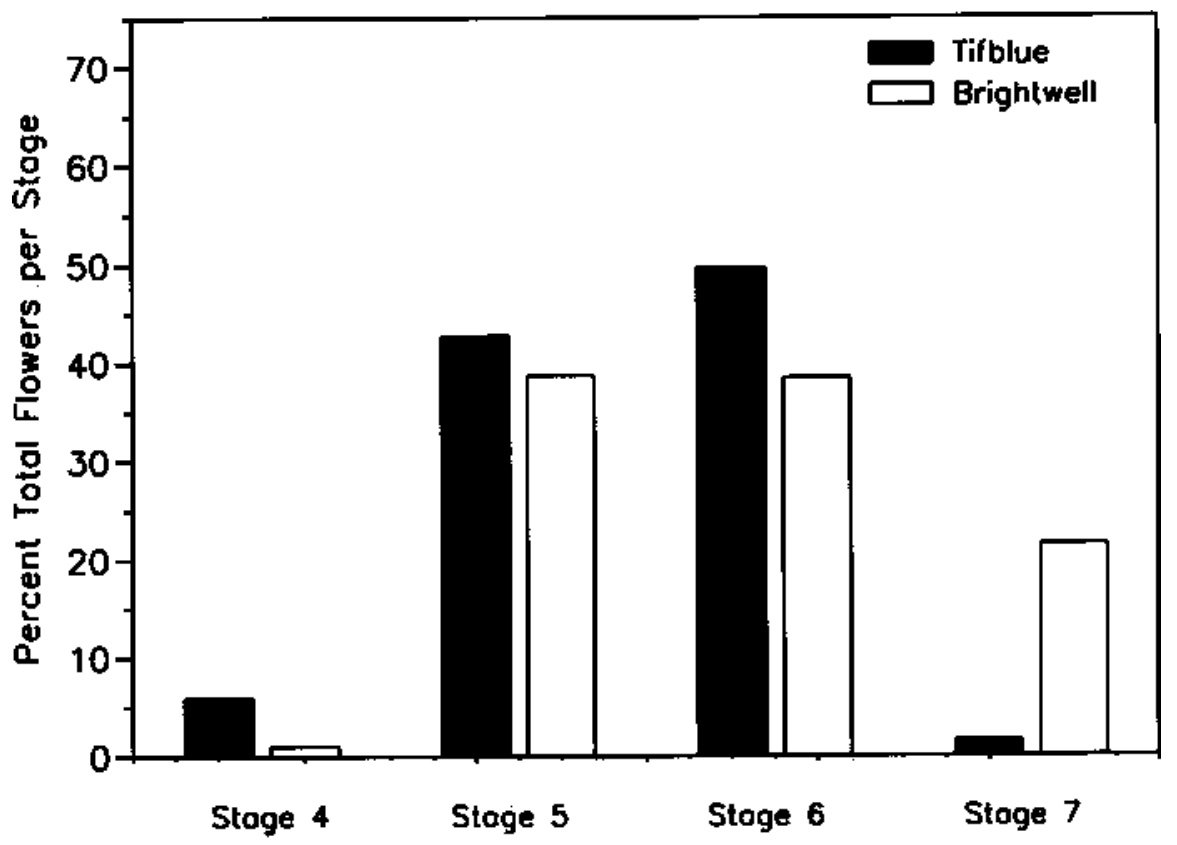

Fig. 1. Percentage of 'Tifblue' and 'Brightwell' flowers at various stages of development (Spiers, 1978) at 
freeze in a controlled-temperature chamber. The freeze event consisted of lowering temperatures in the chamber from 2 to $-2.5 \mathrm{C}$ at a rate of $2 \mathrm{C} / \mathrm{h}$. The lowest temperature of $-2.5 \pm$ $0.5 \mathrm{C}$ was maintained for $\geq 1 \mathrm{~h}$ and then was increased at $2 \mathrm{C} / \mathrm{h}$, and plants were allowed to thaw at $2 \mathrm{C}$ for 2 to $4 \mathrm{~h}$.

Plants were immediately transported back to the greenhouse where they were divided into two groups according to freeze treatment. Half of each group then was sprayed during the day to the point of dripping with a solution containing $\mathrm{GA}_{3}$ (ProGibb 4\%, Abbott Laboratory, North Chicago, Ill.) at $250 \mathrm{mg}^{-1 i t e r}{ }^{-1}$ and Tween 20 surfactant at $0.25 \%$ using a backpack sprayer. The other half of each group was sprayed with water and Tween 20 only. Following $\mathrm{GA}_{3}$ treatments ( 1 to $2 \mathrm{~h}$ of drying time allowed), all plants were randomized on benches in a greenhouse and were subjected to a colony of bumblebees (Bombus impatiens Cresson), containing $\approx 30$ workers, for 3 weeks. These procedures resulted in six plants each of 'Tifblue' and 'Brightwell' that had the following treatment combinations: 1) no $\mathrm{GA}_{3}$, no freeze; 2) $\mathrm{GA}_{3}$, no freeze; 3 ) no $\mathrm{GA}_{3}$, freeze; and 4) $\mathrm{GA}_{3}$, freeze.

The day following freezing and $\mathrm{GA}_{3}$ treatments, three randomly selected shoots with five to 25 flower clusters were tagged on each plant to assess flower numbers and future fruit set. This process resulted in $\geq 100$ flowers being evaluated for each plant. Individual flowers were counted and classified according to stage of development (Spiers, 1978). Fruit set was evaluated by counting individual fruit 3 and 8 weeks after treatments on each sample shoot. Individual fruit from sample shoots for each treatment were harvested at maturity $(\approx 12$ weeks after treatment) to determine fruit weight. Single fruit subsamples (20 to 25 ) were cut open and assigned a seediness score based on seed count, where $0=$ no visible seed, $1=$ less than 10 seeds, $2=11$ to 30 seeds, and $3=$ more than 30 seeds. Data were analyzed statistically to determine main effects and interactions for freezing and $\mathrm{GA}_{3}$ levels. Percent fruit set data were subjected to arcsin-transformation before analysis. Means were separated using least significant difference (LSD) tests.

Induced physical damage. Eight-year-old 'Climax' bushes growing in a field in Chula, Ga., and 12-year-old 'Tifblue' bushes growing in Baxley, Ga., were used to assess the influence of $\mathrm{GA}_{3}$ on fruit set of physically damaged flowers. Flower clusters at stage 5 of development were selected at random on individual bushes and were tagged by putting a tiny dot of white, interior, latex paint above and below the selected flower cluster. The shoot used in the experiment also was tagged to indicate treatment and replication. Physical damage treatments were imposed to flowers on each bush as follows: 1) control, no damage; 2) about two-thirds of the corolla and style removed by cutting with a razor blade through the equator of the flower; 3) about one-half of the style removed with dissecting forceps by making a small hole in the corolla; and 4) ovaries pierced with an insect pin through the equator of the undeveloped berry until the point came out the other side. Following these treatments, half of the bushes remained unsprayed and half were sprayed with $\mathrm{GA}_{3}$ (all selected at random), similar to the methods in the freeze experiment, except 'Climax' received two applications of $\mathrm{GA}_{3}$ six days apart. Also, field applications were made in the early evening or at night to increase drying time, as

Table 1. Effects of gibberellic acid $\left(\mathrm{GA}_{3}\right)$ and freezing on fruit set, fruit weight, and seediness of 'Tifblue' and 'Brightwell' rabbiteye blueberries.

\begin{tabular}{|c|c|c|c|c|c|c|c|}
\hline & & \multicolumn{2}{|c|}{$\begin{array}{c}\text { Fruit set } \\
(\%)\end{array}$} & \multicolumn{2}{|c|}{$\begin{array}{c}\text { Fruit wt } \\
(\mathrm{g})\end{array}$} & \multicolumn{2}{|c|}{$\begin{array}{c}\text { Seediness } \\
\text { score }^{\mathrm{z}}\end{array}$} \\
\hline \multicolumn{2}{|c|}{ Treatments } & \multicolumn{2}{|c|}{ Cultivar } & \multicolumn{2}{|c|}{ Cultivar } & \multicolumn{2}{|c|}{ Cultivar } \\
\hline$\overline{\mathrm{GA}_{3}}$ & $\overline{\text { Freezing }}$ & Tifblue & Brightwell & Tifblue & Brightwell & Tifblue & Brightwell \\
\hline- & - & 8.1 & 22.8 & 1.52 & 1.61 & 1.55 & 2.67 \\
\hline+ & - & 49.2 & 73.2 & 1.13 & 1.08 & 0.91 & 0.75 \\
\hline- & + & 1.3 & 4.2 & 1.43 & 1.29 & 2.60 & 2.75 \\
\hline+ & + & 30.8 & 34.4 & 1.19 & 1.06 & 0.17 & 1.50 \\
\hline $\operatorname{LSD}_{0.0}$ & & 15.4 & 12.3 & 0.32 & 0.19 & 0.57 & 0.67 \\
\hline
\end{tabular}

${ }^{\mathrm{z}}$ See text for description of seediness score.

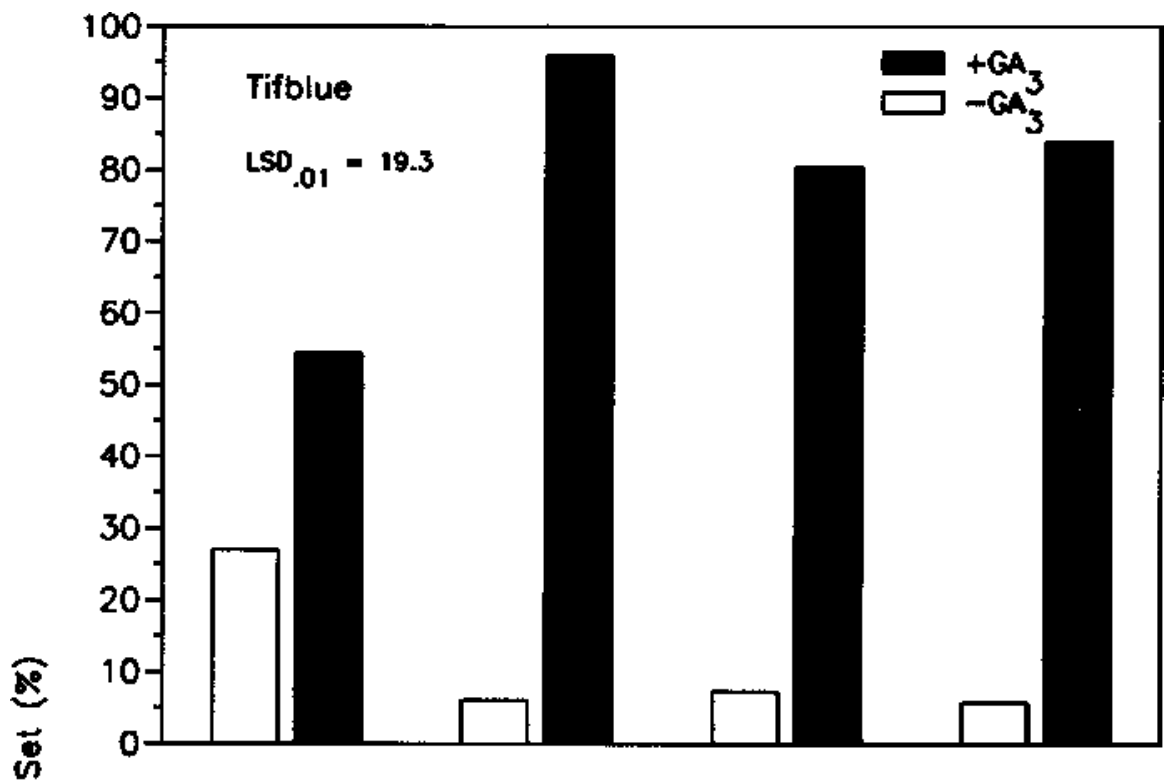

节

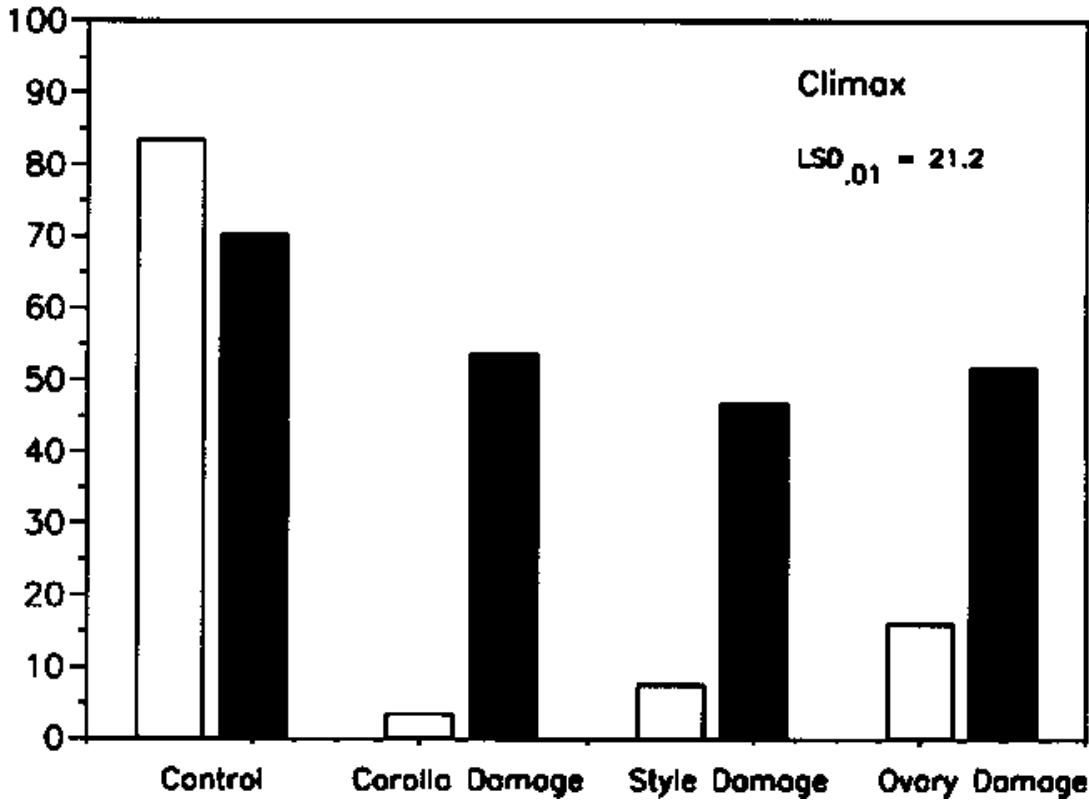

Fig. 2. Fruit set of 'Tifblue' and 'Climax' rabbiteye blueberries with $\left(+\mathrm{GA}_{3}\right)$ and without $\left(-\mathrm{GA}_{3}\right)$ gibberellic acid application following physical flower damage under field conditions. Mean separation for each at $P \leq 0.01$. 
by analysis of variance using arcsin transformation, and means were separated using LSD tests.

\section{Results and Discussion}

Induced freezing. At the time of freezing and $\mathrm{GA}_{3}$ applications, most flowers of 'Tifblue' and 'Brightwell' were at or beyond stage 5 of development(Fig. 1). 'Brightwell' was slightly ahead of 'Tifblue' in bud development as apparent from the greater percentage of flowers at stage 7 for the former cultivar. Flower damage due to freezing was not quantified in this experiment. However, according to Spiers (1978), flowers at such an advanced stage of development as those in this experiment would have sustained substantial damage at $-2.5 \mathrm{C}$. His research indicated that significant flower damage occurred at $-1 \mathrm{C}$ during late stages of development, and $-5 \mathrm{C}$ at late stages of development killed almost all 'Tifblue' flower buds.

Fruit set was affected significantly by freezing and $\mathrm{GA}_{3}$ applications for both cultivars, and there was a significant interaction for 'Brightwell' but not for 'Tifblue' (Table 1). The difference in fruit set for the two cultivars (especially the no- $\mathrm{GA}_{3}$ and no-freeze treatment) may have been related to their differences in flower bud development discussed earlier. Fruit set in the no-GA $\mathrm{G}_{3}$ and no-freeze treatments was low, but we did not consider this to be abnormal, considering the artificial environment and that some rabbiteye blueberries typically exhibit extremely low fruit set when open-pollinated (Davies, 1986; Lyrene and Crocker, 1983; Lyrene and Goldy, 1983). Fruit set of 'Tifblue' with $\mathrm{GA}_{3}$ and no freeze was similar to that shown in an earlier experiment (NeSmith and Krewer, 1992). Nonetheless, freezing significantly reduced fruit set for both cultivars; whereas $\mathrm{GA}_{3}$ applications significantly increased fruit set for the two cultivars, even following freeze conditions. These results strongly suggest that $\mathrm{GA}_{3}$ can be used to salvage a blueberry crop with freezedamaged flowers that might be avoided by bees or that could not be pollinated otherwise.

Freezing did not influence individual fruit weight of 'Tifblue'; however, the addition of $\mathrm{GA}_{3}$ reduced average berry weight (Table 1). There was a significant freeze main effect and $\mathrm{GA}_{3} \times$ freeze interaction for fruit weight of 'Brightwell'. Reasons for the interaction and freeze effects on this cultivar are unclear. $\mathrm{GA}_{3}$ applications reduced average seediness for both cultivars, regardless of freeze treatment. There was a significant $\mathrm{GA}_{3} \times$ freeze interaction for 'Tifblue' seediness, but reasons for this also are unclear.

Reports of lighter, less seedy fruit are common for $\mathrm{GA}_{3}$-treated berries (Davies and Buchanan, 1979; Mainland and Eck, 1969; Williamson et al., 1995). However, $\mathrm{GA}_{3}$ applications do not always reduce fruit weight (Austin, 1979; Collins and Irving, 1971). Reduced fruit weight likely is linked to the absence of seeds. $\mathrm{GA}_{3}$ can substitute to a degree for seeds in certain fruiting organs, but a continuous supply or multiple applications of the growth regulator may be needed to completely overcome the effect of a lack of seed on fruit growth (Pharis and King, 1985). Some of the decreased weight of $\mathrm{GA}_{3}$-treated fruit may have been due to increased fruit load on our plants.

Induced physical damage. $\mathrm{GA}_{3}$ significantly increased fruit set of physically damaged 'Climax' flowers (Fig. 2). Fruit began dropping $\approx 10$ days after petal fall. There was no significant difference in fruit set between the undamaged flowers treated or not treated with $\mathrm{GA}_{3}$. Excellent fruit set $(>70 \%)$ occurred on both. Nontreated but damaged flowers resulted in extremely poor fruit set (4\% to $16 \%$ ). However, with $\mathrm{GA}_{3}$ applied, even the ovary lancing resulted in $>50 \%$ fruit set. For undamaged 'Tifblue' flowers, fruit set was poor in the absence of $\mathrm{GA}_{3}(27 \%)$, whereas fruit set was significantly better with $\mathrm{GA}_{3}(54 \%)$. This is typical for this cultivar, as discussed earlier. Fruit set for each of the physically damaged 'Tifblue' treatments was higher when $\mathrm{GA}_{3}$ was applied, which was similar to the response observed with 'Climax'.

The field experiments provided corroborative evidence that flowers that have suffered damage to the ovary, stigma, style, pollen, or corolla following a freeze can be induced to set fruit with $\mathrm{GA}_{3}$. Casual observations during the growing season and at harvest indicated 'Tifblue' fruit appeared to size better than 'Climax'. As discussed for the greenhouse freeze experiment, it is likely some seeds are needed for good fruit sizing, especially for 'Climax'.

\section{Conclusions}

Results from these field and greenhouse experiments revealed that rabbiteye blueberry fruit set increased due to $\mathrm{GA}_{3}$ applications following physical or freeze damage to flowers. $\mathrm{GA}_{3}$-treated fruit typically were less seedy and weighed less than nontreated fruit. These traits combined may in fact make this a desirable attribute in marketing the fruit, especially for value-added products, such as blueberry raisins. These results suggest that $\mathrm{GA}_{3}$ may prove economically valuable to the blueberry industry in salvaging a crop with freezedamaged flowers. Although $\mathrm{GA}_{3}$ for freeze rescue of blueberries appears promising, there are obviously limits to its value in severe freeze situations. Most of the freezes sustained in the spring in the southeastern United States are of the moderate type, and in these situations, $\mathrm{GA}_{3}$ may be useful. Because 'Tifblue' is $\approx 44 \%$ of the Georgia hectarage (Hubbard et al., 1992), the economic impact of reducing freeze damage on this cultivar alone is potentially high. Additional research is needed to clarify the lower temperature limits of the expected rescue. Other issues, such as cultivar differences, timing of applications related to freeze events, effects of multiple applications, and rates on rescue and the possibility for use in highbush and lowbush blue- berries exposed to freezes remain unresolved. These issues need to be investigated for $\mathrm{GA}_{3}$ to become a tool in managing freeze-damaged blueberry crops.

\section{Literature Cited}

Austin, M.E., 1979. The effect of gibberellic acid on rabbiteye blueberries. Georgia Agr. Res. 20:810.

Barker, W.G. and W.B. Collins. 1965. Parthenocarpic fruit set in the lowbush blueberry. Proc. Amer. Soc. Hort. Sci. 87:229-233.

Collins, W.B. and K.H. Irving. 1971. Evidence for a gibberellin-like substance in flower buds of low bush blueberry under short-day conditions. HortScience 6:492-493.

Davies, F.S. 1986. Flower position, growth regulators, and fruit set of rabbiteye blueberries. J. Amer. Soc. Hort. Sci. 111:338-341.

Davies, F.S. and D.W. Buchanan. 1979. Influence of $\mathrm{GA}_{3}$ on rabbiteye blueberry fruit set, yield, and quality, p. 229-236. In: J.N. Moore (ed.) Proc. IV North Amer. Blueberry Res. Workers Conf., Fayetteville, Ark.

Eck, P. 1988. Blueberry science. Rutgers Univ. Press, New Brunswick, N.J.

Hubbard, E.E., W.J. Florkowski, G.W. Krewer, and H.J. Witt. 1992. Commercial blueberry inventory and prospectus. Univ. of Georgia Agr. Expt. Sta. Res. Rpt. 608, Athens.

Krewer, G., D.S. NeSmith, and M.E. Ferree. 1994 Blueberry growth regulator, p. 239. In: K. Delaplane (ed.). 1994 Georgia pest control handbook. Univ. of Georgia Coop. Ext. Serv. Spec. Bul. 28, Athens.

Lyrene, P.M. and T.E. Crocker. 1983. Poor fruit set on rabbiteye blueberries after mild winters: Possible causes and remedies. Proc. Fla. State Hort. Soc. 96:195-197.

Lyrene, P.M. and R.G. Goldy. 1983. Cultivar variation in fruit set and number of flowers per cluster for rabbiteye blueberry. HortScience 18:228229.

Mainland, C.M., J.T. Ambrose, and L.E. Garcia. 1979. Fruit set and development of rabbiteye blueberries in response to pollinator cultivar or gibberellic acid, p. 203-211. In: J.N. Moore (ed.). Proc. IV North American Blueberry Res. Workers Conf., Fayetteville, Ark.

Mainland, C.M. and P. Eck. 1969. Fruiting response of the highbush blueberry to gibberellic acid under field conditions. J. Amer. Soc. Hort. Sci. 94:21-23.

Modlibowska, I. 1975. Induction of parthenocarpic apples of Bramley's seedling by low concentrations of gibberellins. J. Hort. Sci. $50: 21-22$.

NeSmith, D.S. and G. Krewer. 1992. Flower bud stage and chill hours influence the activity of $\mathrm{GA}_{3}$ applied to rabbiteye blueberry. HortScience 27:316-318

Pharis, R.P. and R.W. King. 1985. Gibberellins and reproductive development of seed plants. Annu. Rev. Plant Physiol. 36:517-568.

Spiers, J.M. 1978. Effect of stage of bud development on cold injury in rabbiteye blueberry. J. Amer. Soc. Hort. Sci. 103:452-455.

Williamson, J.G., R.L. Darnell, G. Krewer, J. Vanerwegen, and S. NeSmith. 1995. Gibberellic acid: A management tool for increasing yield of rabbiteye blueberry. J. Small Fruit Viticult. (In press.)

Zucconi, F. and M.J. Bukovac. 1978. Stimulation of growth in frost-injured peach fruit by gibberellin $A_{3}$. Acta Hort. 80:159-162. 